\title{
Rethinking the History of Smallpox in the Early Twentieth Century: The SS Korea and Uncertainty Surrounding the Diagnosis of Smallpox
}

1. A Missing Piece in the Historical Remembrance of Smallpox

2. Development of Maritime Surveillance of Infectious Diseases and Smallpox Control

3. Troubled Acceptance: Vaccination as a Method of Smallpox Control

4. Smallpox on the SS Korea and the Dispute over Smallpox Diagnosis

5. Reconstructing a Comprehensive Medical Historical Context

\section{A Missing Piece in the Historical Remembrance of Smallpox}

Early on June 1, 1903, local Hawaiian newspapers sounded the alarm about an outbreak of smallpox on the SS Korea, a transpacific carrier that had just arrived in Honolulu from Japan. A twelve-year-old American girl who was traveling with her parents and sister turned out to be the origin of the smallpox infection. Various medical and public health measures

\footnotetext{
* Research Professor, US History and the History of Medicine, Department of History, Ewha Womans University / E-mail: maat782000@gmail.com
} 
LEE Hyon Ju : Rethinking the History of Smallpox in the Early Twentieth Century:

The SS Korea and Uncertainty Surrounding the Diagnosis of Smallpox

were utilized in an attempt to contain the spread of smallpox infection. The young patient was promptly isolated. The ship was quarantined and disinfected, and her passengers were vaccinated. No further cases of smallpox were reported. The SS Korea departed for San Francisco, its final destination, the next day.

The events on the SS Korea sound like an example of successful public health control, in terms of the combination of disease surveillance, quarantine, and vaccination. However, various reports from local newspapers provide evidence that local residents were outraged about the public health measures that were applied to control the spread of smallpox infection. In particular, public suspicions that diagnoses had been concealed and conflicting reports of the true nature of the disease on board the ship tarnished the measures' success.

Smallpox is an infectious disease caused by The Variola major or Variola minor virus. It has no animal or insect vectors, and infection by the virus occurs through the respiratory system. In general, after a sevento ten-day incubation time, signs and symptoms of infection, including fever, backache, and nausea, appear. This is followed by rashes, which become eruptive and produce pustules. Next follows a desquamating stage, in which the scabs fall off, leaving pitted scars on the skin. Smallpox patients are known to have been infectious from the moment signs of infection appeared to the final scabbing stage. Smallpox was an ancient disease which greatly threatened human lives with its high mortality rate and destructive consequences for patients who were able to recover. However, a one-time infection assured life-long immunity.

The history of vaccination begins with the cowpox vaccine against smallpox. Its predecessor technique, smallpox inoculation, or variolation, 
LEE Hyon Ju : Rethinking the History of Smallpox in the Early Twentieth Century: The SS Korea and Uncertainty Surrounding the Diagnosis of Smallpox

which involved using infectious substance from smallpox patients, had been transmitted from Turkey to England and from England to its North American colonies in the early eighteenth century. In 1798, Edward Jenner, a British doctor, introduced inoculation by cowpox, which provided protection against smallpox. The protection turned out to be only temporary, commonly lasting for a four-year period. Since there was, and still is, no cure for smallpox, prevention with vaccination was one of the best individual and public health methods to fight the disease. From the early to late nineteenth century, various European countries, including Sweden, England, and Germany, passed compulsory vaccination laws. By the last decades of the nineteenth century, a large number of states in the United States had also enacted compulsory vaccination laws requiring vaccination for children entering school (Lee, 2018a: 278-284; Lee, 2018b: 9-10). Vaccination also came to be the usual method for maritime smallpox control, along with surveillance and quarantine (Willrich, 2011: 218-227).

The major historiography of smallpox during the late nineteenth century has developed with a main focus on the issues surrounding vaccination policy and resistance to it. ${ }^{1)}$ Compulsory vaccination against smallpox throughout the nineteenth century encountered various kinds of medical, political, social, and religious opposition up to the early twentieth century, as well-illustrated by historians of vaccination Nadja Durback, Michael Willrich, and James Colgrove (Colgrove, 2005: 167-

1) This is equally true for the history of smallpox in earlier periods. Most research has developed around the controversies that swirled around the adoption of vaccination and relevant policies, rather than issues such as the evolution of vaccination technology itself, medical questions relevant to the diagnosis of smallpox, and available therapeutic options. 
LEE Hyon Ju : Rethinking the History of Smallpox in the Early Twentieth Century:

The SS Korea and Uncertainty Surrounding the Diagnosis of Smallpox

191; Colgrove, 2006: 22-29, 41-42; Lee, 2018a: 287-292; Lee, 2018b: 5-16). 2) Their scholarly works on vaccination have provided persuasive accounts of the concerns and suspicions people had about the safety of vaccine lymph and the administration of vaccinations. Furthermore, their scholarship has excavated various issues couched in the late nineteenth century and twentieth century vaccination controversy and underscoring the antivaccination movement, including political and social woes about growing state power over individual matters, class interests, lagging adoption of the germ theory of disease, and conflict among heterogeneous groups of medical professionals in the process of professionalization.

However, ironically, the full attention to the vaccination controversy by the recent historiography has overshadowed the importance of discussing how smallpox, a disease the public was forced to be vaccinated against, was actually diagnosed at the time and to what degree contemporaries deemed a diagnosis as trustworthy. Although Willrich has mentioned the diagnostic difficulty of recognizing smallpox in cases of Variola minor and distinguishing smallpox from chicken pox, the literature at large has not yet inquired deeply into smallpox diagnosis as an essential part of the discussion on the history of smallpox, though it provided the fundamental grounds for justification of public health methods that, while implemented to contain the disease, inevitably infringed on individual liberty and rights. The story of smallpox on the SS Korea is a precious lens through which we can explore this important but left-out piece.

2) Also see Nadja Durback, Bodily Matters: The Anti-Vaccination Movement in England, 1853-1907 (Durham, NC: Duke University Press, 2005); Michael Willrich, POX: An American History (New York: Penguin Books, 2011). 
LEE Hyon Ju : Rethinking the History of Smallpox in the Early Twentieth Century: The SS Korea and Uncertainty Surrounding the Diagnosis of Smallpox

\section{Development of Maritime Surveillance of Infectious Diseases and Smallpox Control}

In the decades after 1870, technological advancements in steamship building powered oceanic travel across both the Atlantic and Pacific Oceans, bringing the United States and the rest of the world closer. While a number of companies competed for sales, the ticket price and the speed of sailing dramatically changed during that time. For both oceanic crossings, steamships carried from several hundred to a thousand passengers on each trip. From the mid-nineteenth century to the early twentieth century, various transpacific carriers were making runs between Asia and the United States, and by 1903, the two worlds were connected to a degree that no one had ever imagined. The Republic of Hawaii, which existed between 1894 and 1898, was annexed by the United States in the summer of 1898, and it remained a US territory until August 1959, when it received statehood. Honolulu, which had been the capital of the Islands since 1845, came to be one of the most important US territories, serving as a waypoint between East Asia and San Francisco on the mainland. Once the US government assumed official responsibility, it controlled immigration and maritime surveillance from Hawaii to monitor the entry of people and diseases into the United States. Honolulu came to be a central location for this process (Barkan, 2013: 1478; Tate, 1986: 29-61; Willrich, 2011: 218).

As more people began traveling by sea, various microbes were communicated across the Pacific. Noticing the danger that increasing international travel posed to public health, in the mid-1870s, the United States developed a more sophisticated surveillance system for 
LEE Hyon Ju : Rethinking the History of Smallpox in the Early Twentieth Century:

The SS Korea and Uncertainty Surrounding the Diagnosis of Smallpox

international disease based on the ideas of John M. Woodworth (18371879), the Supervising Surgeon of the Marine Hospital Service (MHS). In the United States, the concerns of maritime health were embodied in institutional form early on. The MHS was originally created in the late eighteenth century, shortly after the enactment of the 1798 Act for the Relief of Sick and Disabled Seamen. The main role of this institution was to care for sick seamen and build marine hospitals at principal ports along the East Coast. As US territory expanded through the nineteenth century, its ports multiplied on other coasts. In 1871, dispersed and loosely connected marine hospitals in US territory were finally centralized with the appointment of the first Supervising Surgeon and the establishment of MHS headquarters in Washington DC. Having studied pharmacy at the University of Chicago and medicine at Chicago Medical College, Woodworth became the first head of the newly unified MHS and reformed the institution, envisioning it as contributing to a larger public health purpose beyond just caring for seamen (Gostin, 2008: 156). Woodworth had two main reform principles: (1) the best way to control disease was to prevent it from entering the country and (2) it was important to employ a strategic approach that involved building a centralized public health reporting system (Cliff, 1997: 77-78).

In an effort to contain the yellow fever epidemic during the spring of 1878, the US Congress established a notable national system for governing quarantines. The Quarantine Act of 1878 was enacted to prevent introduction of contagious or infectious diseases to the United States. The government accordingly upgraded its international surveillance system to meet the newly recognized international threat of infectious disease by utilizing its diplomatic pooling system (which had been adding 
LEE Hyon Ju : Rethinking the History of Smallpox in the Early Twentieth Century: The SS Korea and Uncertainty Surrounding the Diagnosis of Smallpox

medical personnel since 1893) and the power of mass media (Cliff, 1997: 78; Markel, 1997: 95). Under this system, US consuls were obliged to submit weekly summaries of mortality in their jurisdictions and advise the Supervising Surgeon-General (formerly Supervising Surgeon) of the MHS. The collected reports were then published. The US Public Health Office's Foreign Health Reports published between 1888 and 1912 covered 250 cities from all over the world (Cliff, 1997: 78-82). The 1878 law also granted the right of quarantine to the MHS, along with the National Board of Health (NBH). By the turn of the century, the MHS had grown into a national institution operating in service to public health in general and changed its name to the Public Health and Marine Hospital Service (PHMHS) in 1902 (Smillie, 1943: 925-30; Michael, 2011: 123-129). 3)

Meanwhile, Hawaii had already established its own Western-style public health institutions in the mid-nineteenth century before the annexation. Kamehameha III (1814-1854, reign: 1825-1854), a Hawaiian monarch, in pursuing modernization, tried to balance protection of Hawaii's traditional culture and adoption of Western culture and social systems, and during his reign, the Kingdom of Hawaii gradually went through the modernization process. ${ }^{4}$ In 1850, the King created the first Board of Health in Hawaii for the investigation of cholera (Moran, 2007: 50). At the end of the century, the Board of Health, located in Honolulu, consisted of three physicians, three laymen, and an attorney-general.

3) The NBH existed from 1879 to 1883 . During these years, this institution was briefly vested with the right of quarantine instead of the MHS. In 1912, the PHMHS became the US Public Health Service (PHS).

4) See the recent dissertation by Jannetta Susan Corley, "Literacy, Statecraft and Sovereignty: Kamehameha III's Defense of the Hawaiian Kingdom in the 1840s," PhD diss, (University of Hawaii at Minoa, 2019). 
LEE Hyon Ju : Rethinking the History of Smallpox in the Early Twentieth Century:

The SS Korea and Uncertainty Surrounding the Diagnosis of Smallpox

Its duties encompassed administration over sanitary issues, building of hospitals, controlling leprosy, and quarantine. ${ }^{5)}$

In 1903, however, having become a US territory five years prior, Hawaii was integrated into the US international infectious disease control system. The US government recognized the importance of preventing introduction of diseases that could spread within the country and monitoring the entry of immigrants to mainland America, and it saw a necessity for taking control of this procedure in Hawaii. Soon after Hawaii's annexation, Walter Wyman (1848-1911), the Surgeon General of the PHMHS dispatched Dr. D. A. Carmichael to the Island of Hawaii to conduct leprosy research and supervise maritime quarantine (Michael, 1980: 203-204). ${ }^{6}$ Carmichael sent his first report regarding Hawaii to the PHMHS in 1898. In 1900, the PHMHS gained full control of the operation of the Quarantine Station on Mauliola Island in Honolulu. In 1903, the US federal government made concrete its governance over the immigration process in Hawaii, opening an immigration station in Kaka'ako, Honolulu (Barkan, 2013: 1478). In addition, local newspapers in Hawaii published a column based on reports to the PHMHS titled "Oriental Health" every two weeks that included a record of the cases of communicable diseases mainly in East Asian port cities and the mortality of each disease.

With these developments to the national quarantine system and law, the maritime surveillance system, which was originally mandated in the early eighteenth century, was greatly reinforced by 1903. This advanced system of maritime disease surveillance is epitomized in Quarantine

5) D. A. Carmichael, "Hawaiian Islands. Surgeon Carmichael's Report," Public Health Reports 13 (December 2, 1898), 1414.

6) In 1902, when the MHS was changed to the PHMHS by Wyman, the division chief's title was also simplified from Supervising Surgeon General to Surgeon General. 
LEE Hyon Ju : Rethinking the History of Smallpox in the Early Twentieth Century: The SS Korea and Uncertainty Surrounding the Diagnosis of Smallpox

Laws and Regulations of the United States of 1899, a revision of the 1893 edition: "An act granting additional quarantine powers and imposing additional duties upon the Marine Hospital Service." These quarantine laws applied to all merchant ships and other vessels entering any US port from a foreign port and required a system of procedure involving US consuls in foreign ports, the Secretary of the Treasury, the Supervising Surgeon General of the Marine Hospital Service, and state and municipal boards of health. Any vessel wanting clearance to enter a port in the United States was required to obtain a "Bill of Health" from a US consul, vice-consul, or other consular officer at the place of departure or a medical officer designated by the President. A duplicate of the bill of health certifying the sanitary history and condition of the ship as well as its cargo, passengers, and crew had to be submitted to the Secretary of the Treasury of the United States before entrance. ${ }^{7}$

The bill of health, Form No. 1931a, required a vessel's basic information (name, nationality, rig, master, tonnage, iron or wood, number of compartments for cargo, steerage passengers, and crew) as well as the name of the medical officer on board; number of officers and their family members, crew, and passengers; number of total persons on board; port of departure; last anchorage site; specific trade and type of engagement; number of cases of sickness and character of sickness during the previous voyage; sanitary condition of the vessel and cargo (including its nature); sources and cleanness of the water and food supply; and the sanitary history of officers, crew, passengers, and their effects. The form demanded notification of any diseases prevailing at the port or its

7) Quarantine Laws and Regulations of the United States (Washington: Government Printing Office, 1899), 5. 
LEE Hyon Ju : Rethinking the History of Smallpox in the Early Twentieth Century:

The SS Korea and Uncertainty Surrounding the Diagnosis of Smallpox

vicinity, the location of the vessel during discharge and loading, and the number of cases and deaths from yellow fever, Asiatic cholera, Cholera nostras or cholerine, smallpox, typhus fever, plague, and leprosy during the last two weeks and while the vessel was in the current port. Finally, the form asked if there had been any worrisome public health conditions at the port of departure or its vicinity and required a consular officer's signature. ${ }^{8)}$

The 1899 quarantine laws also included detailed instruction for inspection. To issue a bill of health, a consul could execute an inspection of the vessel, cargo, passengers, crew, personal effects, manifests, papers, food, and water supply in the case of a prevailing yellow fever, smallpox, or typhus fever epidemic at the port of departure. If the vessel departed from a healthy port, inspection was only implemented for steerage passengers. ${ }^{\text {?) }}$

Besides sophisticated traditional methods, such as reporting of sickness on board, isolation of sick and suspected sick persons, quarantine of infected and suspected ships, and disinfection of contaminated vessels, the system was now strengthened by other disease control measures such as ship doctors and hospitals whose duties and locations were clearly defined by the law. A ship physician had to inspect the vessel including the steerage once a day. If he discovered anyone with symptoms of smallpox, cholera, yellow fever, or typhus fever, he was supposed to immediately send them to the hospital and notify the captain. In addition, he was obliged to record all cases of sickness on board on a prescribed form. The "Form for clinical report" required the physician to fill out the

8) Ibid., 12.

9) Ibid., 13-14. 
LEE Hyon Ju : Rethinking the History of Smallpox in the Early Twentieth Century: The SS Korea and Uncertainty Surrounding the Diagnosis of Smallpox

patient's name, age, sex, last permanent residence, date of admission, disease, date of discharge, result, and clinical history. This form was handed to the quarantine officer at the port of arrival. ${ }^{10}$

While the laws generally enforced appropriate sanitary conditions for the vessel, persons, cargo, and materials used for the maintenance of the vessel or provided to passengers, they targeted the containment of specific diseases. They defined six communicable diseases (cholera [cholerine], yellow fever, smallpox, typhus fever, leprosy, and plague) as "quarantinable diseases." Along with this, boarding of patients suffering from scarlet fever, measles, or diphtheria was also prohibited. Depending on the kind of disease, different measures were implemented, with guidelines provided for disinfection of the vessel, passengers, and cargo, disinfection formula, detention rules, and quarantine periods. ${ }^{11)}$ For a suspected smallpox case, the detention period for the passenger covered the disease's incubation time, "not less than fourteen days." ${ }^{12)}$ Any vessel that had a "quarantinable disease on board," or cases of such disease during its voyage or within "thirty days next preceding arrival," or that had departed "from the ports with the diseases in epidemic" was subject to quarantine. ${ }^{13)}$

All vessels from foreign ports were the subject of inspection at the port of arrival. All vessels "from foreign ports carrying passengers having entered a port of the United States without complete discharge of passengers and cargo" needed to go through a second inspection

\footnotetext{
10) Ibid., 19-20.

11) Ibid., 15-17.

12) Ibid., 34 .

13) Ibid., 27.
} 
LEE Hyon Ju : Rethinking the History of Smallpox in the Early Twentieth Century:

The SS Korea and Uncertainty Surrounding the Diagnosis of Smallpox

before it entered any other port. ${ }^{14)}$ During the inspection, if necessary, the quarantine officer could examine the bill of health, the ship doctor's clinical records during the voyage, passenger's lists and manifests, and the ship's log. Except for the quarantine officer, the staff, and US customs officers (or agents of the vessel), nobody could board before the quarantine was completed. If any quarantinable infectious disease was detected, that information was delivered by the quarantine officer to the commissioner of immigration at the port of arrival and finally to the state health authority, where the immigrants headed. ${ }^{15)}$

\section{Troubled Acceptance: Vaccination as a Method of Smallpox Control}

Despite the development of a systematic and meticulous maritime surveillance system, infectious diseases such as smallpox sneaked into US ports as in the case of the SS Korea in 1903. Compared to other quarantinable diseases, smallpox had two conditions that gave people a little advantage in containing it. First, the disease did not have an animal or insect vector, so it could be successfully contained by merely interrupting transmission among people. Second, mankind already had a powerful weapon to increase immunity in the population against the disease-vaccination. Recognizing its effectiveness by the time of the SS Korea's Pacific Ocean crossing, the United States adopted vaccination as an essential part of its international smallpox control. The 1894 Quarantine Laws and Regulations made vaccination against smallpox a required procedure for people who wished to enter US territory.

14) Ibid., 26.

15) Ibid. 
LEE Hyon Ju : Rethinking the History of Smallpox in the Early Twentieth Century: The SS Korea and Uncertainty Surrounding the Diagnosis of Smallpox

However, vaccination as a method of smallpox control was not accepted without trouble.

Prior to its annexation by the United States, the Kingdom of Hawaii went through an important change in regard to vaccination policy at the end of Kamehameha III's reign. Opening the kingdom to other countries and increasing international networks endangered the lives of the Hawaiians due to the growing frequency of infectious diseases. In particular, during a surge of immigration during the California Gold Rush (1848-1855), the Kingdom of Hawaii was exposed to smallpox infection from California. The smallpox epidemic, which lasted between 1853 and 1854, consumed almost 7,000 lives in Hawaii. In Honolulu alone, 2,500 to 3,000 persons perished from smallpox (Kuykendall 1938: 356, 385, 412416). ${ }^{16)}$ In the wake of the epidemic, in 1854, the Hawaiian government executed compulsory vaccination against smallpox. Although Hawaii did not have another smallpox epidemic of this magnitude, the threat of smallpox lingered. A smaller epidemic in 1861 took an estimated 282 lives. During the third attack of smallpox in 1872 and 1873, the spread of infection was effectively sealed off by vaccination, and only eleven deaths were recorded. ${ }^{17)}$ A smallpox epidemic that broke out in 1882 killed another 282 persons. The original source of this epidemic was known to be China. ${ }^{18)}$ Despite vaccination, smallpox remained one of the

16) Hearing before the Committee on Indian Affairs, United States Senate, One Hundred Sixth Congress, Second Session, on S. 1929, to Amend the Native Hawaiian Health Care Improvement Act to Revise and Extend Such Act, Part 5 (Washington: U.S. Government Printing Office, 2000), 477; "Fear of Vaccination," The Pacific Commercial Advertiser, 21 April 1903.

17) Hearing before the Committee, 478; "Fear of Vaccination," The Pacific Commercial Advertiser, 21 April 1903.

18) "Hawaiian Health Timeline and Event," 2016 http://www. papaolalokahi, org/images/ pdf-files/hawaiian-health-time-line-and-events. pdf. (accessed on January 10, 2019.) 
LEE Hyon Ju : Rethinking the History of Smallpox in the Early Twentieth Century:

The SS Korea and Uncertainty Surrounding the Diagnosis of Smallpox

most alarming infectious diseases that international tourists could bring to the islands. The transmission of smallpox was not only a local issue; other port cities on the mainland, such as New York and Boston, had long been exposed to the same.

Thus, in order to prevent the introduction of smallpox from foreign countries to the United States and its territories and the transmission of the disease between states and ports within the nation, the 1894 Quarantine Laws and Regulations finally mandated vaccination for persons entering its lands. A revised version of the laws, the 1899 Quarantine Laws and Regulations, articulated different directions for vaccination that depended on the circumstances of infection (and possibility of infection) surrounding the ports of departure, the vessel, and its people. First, in the case of smallpox breaking out on a vessel during voyage, all persons in the vessel had to be vaccinated. Second, if smallpox prevailed the port of departure, steerage passengers and crew had to submit to vaccination. Third, regardless of an outbreak of smallpox on a vessel and the existence of epidemic smallpox at the place of departure, all passengers except the first or second cabin had to be vaccinated on arrival. To be exempted from the above three cases, a person had to present certification of recent vaccination or prove that they were a smallpox survivor with permanent immunity by presenting smallpox scars on their skin. In each of the second and third cases, a person rejecting vaccination was detained in quarantine for about two weeks. ${ }^{19)}$

As evident from this account of vaccination regulation, the fin-desiècle vaccination policy was discriminatory (Markel, 1997: 92; Willrich,

19) Quarantine Laws and Regulations of the United States, 16, 18, 27-28. 
LEE Hyon Ju : Rethinking the History of Smallpox in the Early Twentieth Century: The SS Korea and Uncertainty Surrounding the Diagnosis of Smallpox

2011: 216-217). The sanitary conditions in steerage were often dangerous and inhumane, and for this reason, the quarantine laws, by and large, divided passengers into two groups, cabin and steerage. The steerage passengers were assumed to be more likely to carry infectious disease, so stricter inspection and disinfection regulations and medical examinations were applied to the steerage passengers and their compartments and belongings throughout boarding, voyage, and landing. For instance, bedding provided to steerage passengers was destroyed or disinfected before reuse or landing. $^{20)}$ If a vessel entered a port of arrival without smallpox on board or no danger from the port of departure had existed, cabin passengers were exempted from smallpox vaccination whereas steerage passengers had no choice. Vaccination as a disease control method was much more coercively implemented for the lower class. Thus, as Willrich explained well, the discriminatory nature of quarantine and vaccination policy often resulted in class confrontation and antivaccination sentiment.

Cowpox vaccination as a disease control measure was not adopted without controversy in the United States and its territories. In the late nineteenth century, a smallpox epidemic originated in the South and spread to the North and the East, and smallpox was recognized as one of the most alarming threats to public health in the country. Many states enacted compulsory vaccination laws for school children, but by the early twentieth century, the antivaccination movement had grown strong with no historical comparison in the United States, as shown by Willrich in Pox: An American History. Despite the fear of smallpox,

20) Ibid., 15, 29. 
LEE Hyon Ju : Rethinking the History of Smallpox in the Early Twentieth Century:

The SS Korea and Uncertainty Surrounding the Diagnosis of Smallpox

when vaccination was applied as a public disease control method, it encountered evasion and resistance. In particular, the 1901-1902 tetanus, or "lockjaw," cases, in which children who were vaccinated with the diphtheria antitoxin and smallpox vaccine in Missouri and New Jersey, respectively, died due to contaminated vaccines, alerted the American public to the possibly unsafe production and administration of vaccines (Lilienfeld, 2008: 192-197; Willrich, 2011: 170-179).

To ease concerns and anxieties over the safety of vaccination, just months before the SS Korea arrived with a smallpox patient at the port of Honolulu, the US federal government made a historic step of regulating the quality of vaccines against smallpox. The transformation was sparked by the previously mentioned lockjaw cases. The government launched a federal investigation into the vaccines contaminated by tetanus toxin (Lilienfeld, 2008: 193-196; Willrich, 2011: 190-193). This was the first investigation of its kind by the government and resulted in the enactment of the 1902 Biologics Control Act, signed by President Theodore Roosevelt (1858-1919) on July 1, 1902. This act regulated all biologics produced and sold in the United States as well as imported goods (Willrich, 2011: 206). It also required pharmaceutical companies in the industry to have a federal license. Willrich argues that after the vaccine crisis, "the Biologics Control Act resolved one of the greatest contradictions in the practice of the nation's burgeoning public health systems: compulsory vaccination of the people without any governmental review of product safety, "and after the act went into effect in 1903, vaccine quality in the United States improved dramatically (Willrich, 2011: 206-207, 209). In the spring of 1903, The Pacific Commercial Advertiser in Hawaii reported that to prevent communication of disease via vaccine lymph, arm-to-arm 
LEE Hyon Ju : Rethinking the History of Smallpox in the Early Twentieth Century: The SS Korea and Uncertainty Surrounding the Diagnosis of Smallpox

vaccination had been prohibited, sterilized needles were used, and only glycerinated fresh calf vaccine was approved for smallpox vaccination, and it criticized the lingering fear of vaccination based on the belief that it could convey other diseases, especially leprosy, as unreliable and unscientific. $^{21)}$

However, the story of smallpox on the SS Korea reveals that the US government's quarantine and vaccination policy against the disease was also founded on uncertainty originating from the medical and scientific limitations of the age. Further, the uncertainty held by contemporary medical personnel and the general public was much greater than historians of smallpox have recognized.

\section{Smallpox on the SS Korea and the Dispute over Smallpox Diagnosis}

The SS Korea was a proud symbol of the new transpacific era, by which the world would become smaller and more connected. She was newly built by the Newport News Shipbuilding and Drydock Company in 1902 along with her sister ship, the SS Siberia. The vessel's name reveals its own history. The SS Korea was a civil carrier, "SS," meaning shipping and sailing or steamship. In 1915, the Korea, along with the Siberia, was sold to the Atlantic Transport Company, and then to Toyo Kisen Kaisha in 1916. During that time, it was renamed SS Korea Maru (Tate, 1986: 35-36, 63). ${ }^{22)}$ In 1903, the SS Korea and SS Siberia were run by the Pacific Mail

21) The Pacific Commercial Advertiser, 21 April 1903.

22) "The Fleets: Toyo Kisen Kabushiki Kaisha/ Toyo Kisen Kaisha/ Oriental Steamship Company, Yokohama," The Specialist, November 10, 2007, http://www. theshipslist. com/ships/lines/tkk. shtml (accessed on August 10, 2019). 
LEE Hyon Ju : Rethinking the History of Smallpox in the Early Twentieth Century:

The SS Korea and Uncertainty Surrounding the Diagnosis of Smallpox

Steamship Company (PMSS). The Korea was one of the biggest carriers in operation. It was 11,300 tons and was capable of carrying about 150 cabin passengers, more than 300 passengers in steerage, and 10,000 tons of cargo. The Korea could cover the 4,500-mile eastbound passage in 10 days, 15 hours, and 15 minutes, and it was the fastest carrier until defeated by the Siberia. A number of people gathered in Honolulu to witness the spectacle of the Korea's first departure in 1903 (Tate, 1986: 35-36). According to a local Hawaiian newspaper, that spring, the Korea had been in Manila before it arrived in East Asia. Passing through Hong Kong, Yokohama, and Honolulu, it was destined to arrive in San Francisco. ${ }^{23)}$

From the winter of 1902 to the spring of 1903, there had been continuous reports of smallpox cases in Shanghai and Hong Kong. In May, about a month before the return of the SS Korea to Honolulu, there were still reports of smallpox outbreaks in Hong Kong and three smallpox cases in Kobe, Japan, whereas Nagasaki and Shanghai were reported to be clean. ${ }^{24)}$ According to a later report on June 1 by local newspaper The Hawaiian Star, quarantine officers in the ports of Manila, Hong Kong, and Yokohama considered holding the SS Korea for suspected smallpox cases, which were later found to be chicken pox. On May 4, the Korea

23) "Korea Brings Smallpox," The Hawaiian Star, 1 June 1903. The Pacific Mail Steamship Company's 1915 advertisement for its transpacific carriers also shows that the SS Korea sailed from San Francisco for "HONOLULU-JAPAN-CHINA-PHILIPPINES" for more than a decade of time. The Pacific Mail Steamship Company advertisement in California Expositions brochure, "The California Expositions Opening on Time" (1915), https://archive.org/stream/C1002013152/c100_2013_152\#page/n14/mode/1up (accessed on March 25, 2020).

24) The Pacific Commercial Advertiser, 22 January 1903; The Independent, 17 April 1903; The Pacific Commercial Advertiser, 23 April 1903; The Pacific Commercial Advertiser, 21 May 1903; Hawaiian Gazette, 22 May 1903. 
LEE Hyon Ju : Rethinking the History of Smallpox in the Early Twentieth Century: The SS Korea and Uncertainty Surrounding the Diagnosis of Smallpox

arrived in Hong Kong where it was briefly quarantined due to a suspected incidence of smallpox. ${ }^{25)}$ The ship then set sail for Yokohama, Japan, and finally arrived in Honolulu on the morning of June 1 with a young smallpox patient.

As soon as the ship anchored in Honolulu, Dr. Leland E. Cofer, an officer from the Honolulu Quarantine Station and successor to D. A. Carmichael, went to the ship. Dr. Cofer confirmed the young patient's sickness as smallpox and carried out the process of vaccination, disinfection, and quarantine to prevent further spread of infection, as detailed in the previous sections. Since the vessel had entered the harbor with a smallpox case on board, according to the quarantine laws and regulations, all passengers in cabin and steerage without evident physical marks of smallpox survival or certification of recent vaccination were subject to a two-week quarantine or vaccination. About two hundred persons on board the vessel received vaccination. All passengers in the cabin who wanted to disembark in Honolulu, even if only for a stroll, were vaccinated. The passengers in steerage were at once quarantined for vaccination and disinfection through bathing, and their baggage was also disinfected. The suite occupied by the sick girl and her family was fumigated and sealed. The SS Korea remained in a channel near the Healani boat house and pilot house in Honolulu harbor for several hours while the steerage passengers were moved to the quarantine location. Then the ship proceeded to the Bishop Slip to unload its cargo. ${ }^{26)}$ The sick girl, her family (parents and sister), and their governess were transferred to a

25) “Korea Brings Smallpox," The Hawaiian Star, 1 June 1903.

26) Ibid. 
LEE Hyon Ju : Rethinking the History of Smallpox in the Early Twentieth Century:

The SS Korea and Uncertainty Surrounding the Diagnosis of Smallpox

quarantine hospital on Mauliola Island, near the entrance to the harbor. ${ }^{27)}$ The Hawaiian Government had leased this privately owned thirty-acre island formed by soft coral for the purpose of maritime quarantine. The Mauliola quarantine complex was composed of twenty-two buildings, including "detention barracks for steerage passengers and immigrants, disinfecting house (containing a steam chamber and Sulphur furnace), electric-light plant, hospitals for contagious and noncontagious disease, quarters for cabin passengers, attendants' quarters, bath houses, waterclosets, etc." ${ }^{28)}$ It had a clean water supply from Honolulu, and a threequarter-mile tramway conveyed baggage and supplies from the harbor to the quarantine station. During this time, as the influx of labor from East Asia grew, a number of Chinese and Japanese people were detained or passed through the quarantine location annually before heading to their final destinations, such as sugarcane and coffee plantations on the Hawaiian Islands. ${ }^{29)}$ The quarantine complex on Mauliola Island was essential to Honolulu's maritime disease control under the US quarantine laws and regulations.

Since only one case of smallpox was detected on the SS Korea, the maritime disease control process did not delay the vessel's departure for the next stop. At 5 p.m. on June 2, it departed for San Francisco on time. However, the smallpox incident had greatly lowered the number of passengers, reflecting the great fear they had. It carried "few passengers from Honolulu." ${ }^{30)}$ Being afraid of smallpox infection, a number of people had canceled their booking, and they instead took the Alameda

27) "Horst Family over at Mauliola Island," Evening Bulletin, 3 June 1903.

28) Carmichael, "Hawaiian Islands," 1414.

29) Ibid.

30) "Korea Leaves for San Francisco," The Pacific Commercial Advertiser, 3 June 1903. 
LEE Hyon Ju : Rethinking the History of Smallpox in the Early Twentieth Century: The SS Korea and Uncertainty Surrounding the Diagnosis of Smallpox

and the Moana. ${ }^{31)}$ The Korea arrived in the harbor of San Francisco on the morning of June 8 . The empty vessel docked with little fanfare and no further quarantine was ordered; this calm was in contrast to the worries still being expressed back in Hawaii by the Korea's previous passengers and the local newspaper. ${ }^{32)}$ In mid to late June, the sick girl and her family were released from the Mauliola quarantine hospital. ${ }^{33)}$ The morning after their hospital discharge, they set sail on the Hongkong Maru, which carried eight persons to San Francisco. ${ }^{34)}$ It seemed like the inspection, prompt vaccination, and quarantine had successfully contained smallpox on the Korea with no further outbreaks. However, public outcry arose in the local community.

Hostility toward and distrust of the upper class, who had been physically separated in the vessel and enjoyed more freedom under the quarantine law, cast a shadow over interpretations of what happened on the SS Korea. On the morning of June 1, local newspaper reporters were not able to identify the sick person because their family name had been suspiciously concealed as they occupied a first-class cabin. In the afternoon, the sick girl was identified as one of the daughters of E. C. Horst, "a prominent San Francisco feed, wheat and shipping merchant." ${ }^{35)}$ On June 2, the

31) "Korea Brings Smallpox," The Hawaiian Star, 1 June 1903; "Moana Tarries but Six Hours" and "Korea Leaves for San Francisco," The Pacific Commercial Advertiser, 3 June 1903 .

32) "Serious Negligence in Matter of Korea’s Smallpox," The Pacific Commercial Advertiser, 2 June 1903; "Korea Leaves for San Francisco," The Pacific Commercial Advertiser, 3 June 1903; Evening Bulletin, 10 June 1903.

33) The Pacific Commercial Advertiser, 20 June 1903; The Pacific Commercial Advertiser, 21 June 1903; Hawaiian Gazette, 23 June 1903.

34) The Hawaiian Gazette, 23 June 1903.

35) "Serious Negligence in Matter of Korea’s Smallpox," The Pacific Commercial Advertiser, 2 June 1903. 
LEE Hyon Ju : Rethinking the History of Smallpox in the Early Twentieth Century:

The SS Korea and Uncertainty Surrounding the Diagnosis of Smallpox

second day of the ship's quarantine, The Pacific Commercial Advertiser published interviews with more passengers from the Korea, and based on their testimonies, the press brought forth various criticisms regarding the system and the measures that maritime disease control had executed over the smallpox case on the vessel.

First, the second day report in The Pacific Commercial Advertiser questioned when the girl had begun to be sick. Diverging from the original report, the newspaper informed the public that the girl had been sick in Yokohama before boarding the SS Korea. Second, this assertion led to the question of how she had been able to get on the vessel, hence causing the physician who attended Horst's daughter to receive uncomfortable public attention. William R. Cluness of San Francisco, medical director of the Pacific Mutual Life Insurance Co. of California and a friend of Mr. Horst, was identified as the doctor who had taken care of the sick girl since Yokohama. One of the passengers testified that Cluness had diagnosed the girl's sickness as measles, and "upon his certificate, the child was allowed on board." ${ }^{36)}$ Third, this allegation that the diagnosis was wrong at best and false at worst augmented the blame aimed at the doctor's irresponsible character. Some passenger accused him of spreading the word that "the disease was nothing but measles." His every action on the ship was judged as evidence of his carelessness in attending a patient with an infectious disease. People were upset about his moving freely on the ship, concealing the true nature of the disease that he was dealing with, and possibly exposing all the passengers to smallpox. A passenger complained that

36) Ibid. 
LEE Hyon Ju : Rethinking the History of Smallpox in the Early Twentieth Century: The SS Korea and Uncertainty Surrounding the Diagnosis of Smallpox

the doctor would be called from the card table or the dinner table to see the child and after treating it would return to his seat. And there was I with children in my charge; and all those passengers as well as myself exposed. Who knows but the whole ship's company is infected? ${ }^{37)}$

Responding to the criticism, the third day report in The Pacific Commercial Advertiser came to the defense of Dr. Cluness. It evaluated the accusations against the doctor as "injustice" and described him as trustworthy, explaining he was a "venerable and kindly man his face is a passport to confidence." ${ }^{38)}$ Cluness confirmed that the daughter of the Horsts had not been sick before getting on board and had not been ill three days before the arrival of the SS Korea at Honolulu Harbor. In addition, he defended himself from the allegation that he was careless in attending a patient with an infectious disease by clarifying that he was never "called from table, cards or smoking room to attend the Horst Child." 39$)$

Aside from the allegations against Cluness, the most important question everyone wanted an answer to was what disease actually broke out on the ship. This question pierced through all the discussions from the beginning to the end of the incident. Two hundred people had gone through vaccination. The identified patient and her family were quarantined. Cluness's public and professional reputation was ruined. The image of the Korea as one of the promising new generation of pacific carriers was tarnished, and its owner, the Pacific Mail Steamship

37) Ibid.

38) "Dr. Cluness' Side of the Korea Smallpox Incident," The Pacific Commercial Advertiser, 3 June 1903.

39) Ibid. 
LEE Hyon Ju : Rethinking the History of Smallpox in the Early Twentieth Century:

The SS Korea and Uncertainty Surrounding the Diagnosis of Smallpox

Company, could not help but suffer economic loss from this incident. Honolulu's quarantine officers were occupied with implementing the quarantine and mandatory vaccination, but the public questioned what the actual disease was that they were quarantined for, vaccinated against, and feared. The very first report on the smallpox incidence on the Korea had confidently reported that "the sick child has a well developed case of the disease. There was not the slightest question as to the nature of her sickness. ${ }^{{ }^{40)}}$ However, this claim was hollowed in an inundation of confusing descriptions of the patient's illness and changing diagnoses. None of the interested parties except for the public health officers had a clear answer to the question.

Local newspapers attempted to trace clues they believed would bring them closer to the substance of the enemy that they were fighting against, and they vigilantly reported various medical opinions, adding more confusion in consequence. Via various interviews with passengers, journalists discovered that the sick girl's sister had been ill before boarding. What had been the disease? Was it the same as that of the other girl who was diagnosed with smallpox by a Honolulu quarantine doctor? When did the sister recover and when did the other girl begin to feel sick? No concurrent diagnoses appeared.

Multiple doctors had examined the young Horst girls from Japan to San Francisco, and they had made multiple diagnoses of their suffering. In chronological sequence, the first doctor to examine Mr. Horst's daughters was Dr. Charlotte B. Brown, called “one of San Francisco's leading lady physicians. "11) She examined the Horst children in Tokyo before the

40) “Korea Brings Smallpox," The Hawaiian Star, 1 June 1903.

41) "Was It or Was it not-Illness of Horst Child Quarantined for Smallpox," Evening 
LEE Hyon Ju : Rethinking the History of Smallpox in the Early Twentieth Century: The SS Korea and Uncertainty Surrounding the Diagnosis of Smallpox

family left for Yokohama. She diagnosed one of the girls with chicken pox, and an unidentified local doctor called to confirm her diagnosis. The sick girl recovered and the Horsts moved on to Yokohama. There, Dr. Cluness examined the child on board the SS Korea. According to him, three days after leaving the port of Yokohama, he diagnosed the child with colie. Three days before arriving at the port of Honolulu, a rash had appeared. Cluness, along with the ship's doctor, speculated her illness was "Manila rash." " According to a June 3 report in The Pacific Commercial Advertiser, Cluness recognized that "smallpox was apprehended" two days before arriving in Honolulu - his account was notably different from that of the passengers who had previously accused Cluness of diagnosing the sickness as measles. A fifth person, Dr. Leland Cofer, a quarantine doctor, finally pronounced the girl's sickness as smallpox at the port of Honolulu. Based on this confirmation, the patient was sent to the quarantine hospital. The quarantine physicians on Mauliola Island were "determined not to discharge the patient as long as the skin shows the slightest signs of scales or postules. ${ }^{433}$

In mid-July, the Evening Bulletin published an interesting follow-up titled "Was It or Was it not-Illness of Horst Child Quarantine for Smallpox." The newspaper introduced the smallpox incidence on the SS Korea as having "bid fair to prove one of the most interesting in the annals of the trans-Pacific quarantine service. " ${ }^{44)}$ According to the report, after being discharged from the quarantine hospital, the Horst child was sent to San

Bulletin, 14 July 1903.

42) Ibid.

43) “Horst Family over at Mauliola Island," Evening Bulletin, 3 June 1903.

44) "Was It or Was it not-Illness of Horst Child Quarantined for Smallpox," Evening Bulletin, 14 July 1903. 
LEE Hyon Ju : Rethinking the History of Smallpox in the Early Twentieth Century:

The SS Korea and Uncertainty Surrounding the Diagnosis of Smallpox

Francisco with her family, where she was strangely quarantined again on Angel Island. The physicians at the quarantine hospital on Angel Island diagnosed her with inflammatory rheumatism and questioned the Honolulu quarantine doctor's final diagnosis of smallpox, saying, "It is doubtful whether she ever had smallpox." ${ }^{45)}$ The report clarified if the disease that she had been originally quarantined for was smallpox, "it is hardly possible the child could have suffered a second attack of smallpox." Dr. Brown, the physician who had examined the girl in Japan, augmented the uncertainty with her retrospective diagnosis, wondering "whether after all the child's illness was not an aggravated form of dengue fever or chicken pox." ${ }^{\text {66) }}$

The varying diagnoses reveal that diagnosis of smallpox was still not an easy task in the early twentieth century. In a nutshell, although about three decades had passed since Robert Koch's discovery of tubercle bacillus, laboratory medicine could not yet help with the diagnosis of smallpox, which was a viral disease whose pathogens were smaller than bacterium. By this time, laboratory medicine was helpful in diagnosing cholera and leprosy. However, this was unfortunately not the case for smallpox. "Précis upon the Diagnosis and Prevention of Smallpox," published in 1899 by the US Marine Hospital Service, mentioned nothing about laboratory tests for the diagnosis of smallpox. Instead, it focused on detailed accounts of incubation time, mode of invasion, pattern and distribution of eruption, and desquamation. It further explained how to distinguish smallpox from other possibly confusing, eruptive and feverish diseases such as measles, scarlet fever, chicken pox, impetigo

45) Ibid.

46) Ibid. 
LEE Hyon Ju : Rethinking the History of Smallpox in the Early Twentieth Century: The SS Korea and Uncertainty Surrounding the Diagnosis of Smallpox

contagiosa, syphilis, cerebro spinal fever, typhus fever, and glanders. ${ }^{47)}$

The size of the Variola virus is quite big, approximately three times bigger than the size of the influenza virus, whose existence was still controversial during the well-known pandemic outbreak at the end of the First World War. British physician John Buist of Edinburgh made the first laboratory viral diagnosis of variola in 1886 by directly detecting virus particles in smallpox lesions. Buist worked as a medical superintendent at the smallpox hospital in Barrow-in-Furness in England and published the book Vaccinia and Variola: A Study of their Life-History in 1887. However, by 1903, it seems that virological knowledge of the cause of smallpox had not yet received the attention of medical scientists, and laboratory tests for the virus could not be utilized to diagnose smallpox. On April 23, 1903, a little more than a month before the arrival of the SS Korea, a Hawaiian newspaper reported that a Cleveland doctor had discovered streptococci, which is the germ "that causes most of the deaths of smallpox patients." ${ }^{48)}$

Diagnostic technology for smallpox gradually developed through the early decades of the twentieth century. Nevertheless, mankind was able to see only a few viruses before the first electronic microscope was created and began to be more frequently used in the 1930s and 1940s. It was not until 1937 that Dr. Mervyn Gordon confirmed Buist's discovery of the smallpox virus in the Edinburgh Medical Journal (Mackie \& Rooyen, 1937: 72-77). ${ }^{49)}$ In 1948, the chicken pox virus and the Variola virus were finally

47) "Précis upon the Diagnosis and Prevention of Smallpox," Public Health Reports 14 (January 6, 1899): 37-42.

48) "Boston Doctor Has Found Germ That Causes Small Pox," The Pacific Commercial Advertiser, 27 April 1903.

49) Also, see “John Buist and the Elementary Bodies of Vaccinia," Nature 139 (1937), 541. 
LEE Hyon Ju : Rethinking the History of Smallpox in the Early Twentieth Century:

The SS Korea and Uncertainty Surrounding the Diagnosis of Smallpox

differentiated through electron microscopic observations (Goldsmith \& Miller, 2009: 552). During the first half of the century, three laboratory methods-variola-vaccinia flocculation, complement-fixation, and Paul's rabbit cornea test-were developed, but these procedures were available only for the later phase of smallpox, and they were not utilized to make any noticeable progress in the number of accurate diagnoses either (Toomey \& Gammel, 1927:29-31; Rooyen \& Illingworth, 1944: 526).

In their 1944 article, "Laboratory Test for Diagnosis of Smallpox," C. E. van Rooyen and R. S. Illingworth from the Royal Army Medical Corps (RAMC) lamented,

\begin{abstract}
While the existence of the minute organisms has been known for many years, it is strange that few bacteriologists have attempted to utilize them for the laboratory diagnosis of smallpox, despite the fact that their biological characteristics have been extensively studied. (Rooyen \& Illingworth, 1944: 527)
\end{abstract}

In 1903, when the SS Korea faced its smallpox crisis, a laboratory test to confirm diagnosis of smallpox does not seem to have been tried. Rather, clinical knowledge and observation of the signs and symptoms of the disease seem to have been the doctors' regular tools for making a diagnosis. T. F. Ricketts's The Diagnosis of Smallpox, published in 1908, provided a substantial clinical description of the distribution of eruptions, rashes, pustules, and lesions on smallpox patients to provide accurate guidance for the confirmation of smallpox. Ricketts, who was a medical superintendent of smallpox hospitals and the River Ambulance Service of the Metropolitan Asylums Board, included 12 color plates and 100 
LEE Hyon Ju : Rethinking the History of Smallpox in the Early Twentieth Century: The SS Korea and Uncertainty Surrounding the Diagnosis of Smallpox

black-and-white plates in order to illustrate different smallpox cases, expanding his 154 pages of text to 460 pages total. ${ }^{50)}$

No one ever provided a clear answer concerning the actual disease that had been quarantined, disinfected, and vaccinated against in Honolulu. There could have possibly been no need for all of the preventative methods that were used, judging from the dispute over the accuracy of the diagnosis. In 1903, these methods proceeded with uncertainty rather than certainty. Although vaccines were tested in the laboratory out of safety concerns in the early twentieth century, diagnosis of smallpox depended on clinical observations rather than confirmation of the existence of Variola virus in the patient. Diagnosis made by experienced doctors in the later phases of smallpox had little room for error. However, more difficulty and confusion were embedded in minor cases and diagnoses in the earlier stages of smallpox infection. In addition, the lack of diagnostic laboratory apparatus made the diagnosis of smallpox in these cases more disputable, challenging the reliability of public health measures in controlling the disease.

\section{Reconstructing a Comprehensive Medical Historical Context}

In 1980, the World Health Organization announced that smallpox was eradicated. Effective disease surveillance and vaccination, utilized over several decades in the mid-twentieth century finally ended the life of smallpox on the globe. ${ }^{51)}$ This triumphant victory over the disease is one of the most recalled memories in the history of disease and medicine.

50) T. F. Ricketts, The Diagnosis of Smallpox (New York: Cassell and Company, 1908).

51) Although fear has returned regarding its possible use as a weapon of bioterrorism. 
LEE Hyon Ju : Rethinking the History of Smallpox in the Early Twentieth Century:

The SS Korea and Uncertainty Surrounding the Diagnosis of Smallpox

The focus on that particular memory, however, has taken attention away from the years of uncertainty over smallpox diagnosis, possibly a fundamental reason behind resistance against vaccine and vaccination policy. Furthermore, the relatively early existence of a vaccine against smallpox has disguised how much this disease was differently diagnosed until the early twentieth century and the limitations and confusion that many faced in the process.

The story of the SS Korea serves to the historian as an interesting lens through which to study undiscovered aspects of the transpacific communication of smallpox several decades before the global eradication program even began. In deepening our understanding of the limits and problems involved in maritime surveillance and diagnosis of smallpox and onboard vaccination at the dawn of the twentieth century, we are reminded of the necessity of placing medical science, vaccination policies, and responses to vaccination in an equitable historical context. This context is essential but largely absent in the current historiography of smallpox and vaccination, so the story of the SS Korea presents an important opportunity to look beyond the idealized aspects of vaccination to explore the realities that contemporaries shared.

The 1903 smallpox case on the SS Korea is important because it reveals how the justifiability of public health measures including quarantine and vaccination was tested in the social and medical science contexts of the early twentieth century. Under discriminatory quarantine and vaccination policies, people lost confidence in the transparency of the diagnostic process and the reporting of disease to authorities of maritime surveillance and quarantine. In addition, the controversy of the 1903 SS Korea smallpox case reveals to what degree diagnosis of smallpox was 
LEE Hyon Ju : Rethinking the History of Smallpox in the Early Twentieth Century: The SS Korea and Uncertainty Surrounding the Diagnosis of Smallpox

confusing in the early twentieth century and how the uncertainty was magnified within the contemporary maritime surveillance system, finally augmenting public anxiety.

Inclusion of this missing diagnosis perspective will revamp the historical context that we currently stand on. It will help us check that we have asked the right questions and lead us to a new set of questions necessary to place the medical experience of an age in its own historical context. Accurate diagnosis of infectious disease is an important premise in the justification of quarantines and civil obedience for public health disease control. In his book State of Immunity, James Colgrove explained that by the mid-twentieth century, the memory of the anti-vaccination movement of the late nineteenth and early twentieth centuries redirected the course of vaccination policy in the United States, from coercion to persuasion, in an attempt to lower public resistance. However, we might also need to consider the role that improved diagnostic technology in the mid-twentieth century had in reconfiguring the relationship between medicine, citizens, and governing entities, especially in regard to public health issues such as the containment of communicable disease.

Keywords: smallpox, quarantine, vaccination, maritime disease control, diagnosis, 천연두, 격리, 백신접종, 해상질병통제, 진단 
LEE Hyon Ju : Rethinking the History of Smallpox in the Early Twentieth Century:

The SS Korea and Uncertainty Surrounding the Diagnosis of Smallpox

\section{REFERENCES}

\section{Primary Sources}

\section{$\langle$ Newspapers $>$}

Evening Bulletin

Hawaiian Gazette

The Hawaiian Star

The Independent

The Pacific Commercial Advertiser

\section{〈Others〉}

Carmichael, D. A., "Hawaiian Islands. Surgeon Carmichael's Report," Public Health Reports 13 (December 2, 1898), pp. 1413-1422.

Hearing before the Committee on Indian Affairs, United States Senate, One Hundred Sixth Congress, Second Session, on S. 1929, to Amend the Native Hawaiian Health Care Improvement Act to Revise and Extend Such Act, Part 5 (Washington: U.S. Government Printing Office, 2000).

Pacific Mail Steamship Company advertisement in California Expositions brochure, "The California Expositions Opening on Time" (1915), https://archive.org/ stream/C1002013152/c100_2013_152\#page/n14/mode/1up. Accessed March 25, 2020.

"Précis upon the Diagnosis and Prevention of Smallpox," Public Health Reports 14 (January 6, 1899), pp. 37-49.

Quarantine Laws and Regulations of the United States (Washington: Government Printing Office, 1899).

\section{Secondary Sources}

Barkan, Elliott Robert, ed. Immigrants in American History: Arrival, Adaptation, and Integration (Santa Barbara, California: ABC-CLIO, 2013).

Cliff, Andrew D. et al., "The Importance of Long-Term Records in Public Health Surveillance: The US Weekly Sanitary Reports, 1888-1912, Revisited,” Journal of Public Health Medicine 19 (1997), pp. 76-84.

Colgrove, James, State of Immunity: The Politics of Vaccination in Twentieth-Century 
LEE Hyon Ju : Rethinking the History of Smallpox in the Early Twentieth Century: The SS Korea and Uncertainty Surrounding the Diagnosis of Smallpox

America (Berkeley: University of California Press, 2006).

, “Science in a Democracy': The Contested Status of Vaccination in the Progressive Era and the 1920s," Isis 96 (June 2005), pp. 167-191.

Corley, Jannetta Susan, "Literacy, Statecraft and Sovereignty: Kamehameha III's Defense of the Hawaiian Kingdom in the 1840s," PhD diss, University of Hawaii at Manoa, 2019.

Goldsmith, Cynthia S. and Sara E. Miller, "Modern Uses of Electron Microscopy for Detection of Viruses," Clinical Microbiology Reviews 22 (4) (2009), pp. 552563.

Gostin, Lawrence O., Public Health Law: Power, Duty, Restraint (University of California Press, 2008).

"Hawaiian Health Timeline and Event," 2016 http://www. papaolalokahi. org/images/ pdf-files/hawaiian-health-time-line-and-events.pdf. Accessed January 10, 2019.

“John Buist and the Elementary Bodies of Vaccinia," Nature 139 (1937), p. 541.

Kuykendall, Ralph S., The Hawaiian Kingdom, vol. 1. 1778-1854 Foundation and Transformation (Honolulu: University of Hawaii Press, 1938).

Lee, Hyon Ju, "19세기에서 20세기 중반 한국의 우두법 및 백신접종 연구에 있어 지구 사적 관점(global perspective)의 유용성," [Global Perspective in Analyzing the History of Cowpox Vaccine and Vaccination in Korea from the Nineteenth Century to the Mid-twentieth Century] The Dong Gook Sa Hak 65 (2018a), pp. 267-313.

"미국에서의 백신 반대 운동," [The Antivaccination Movement in the United States] Korean Journal of American History 47 (2018b), pp. 1-34.

Lilienfeld, D. E., “The First Pharmacoepidemiologic Investigations: National Drug Safety Policy in the United States, 1901-1902," Perspectives in Biology and Medicine 51 (Spring 2008), pp. 188-198.

Mackie, T. J. and C. E. van Rooyen, "John Brown Buist, M.D. (Edin.), B. Sc. (Edin.), F.R.C.P.Ed., F.R.S.Ed. (1846-1915): An Acknowledgment of His Early Contributions to the Bacteriology of Variola and Vaccinia," Edinburgh Medical Journal 44 (February, 1937), pp. 72-77.

Markel, Howard, Quarantine!: East European Jewish Immigrants and the New York City Epidemic of 1892 (Johns Hopkins University Press: Baltimore and 
LEE Hyon Ju : Rethinking the History of Smallpox in the Early Twentieth Century:

The SS Korea and Uncertainty Surrounding the Diagnosis of Smallpox

London, 1997).

Michael, Jerrold M., "The National Board of Health: 1879-1883," Public Health Chronicles 126 (1) (2011), pp. 123-129.

, "The Public Health Service Leprosy Investigation Station on Molokai, Hawaii, 1909-13-An Opportunity Lost,” Public Health Reports 95 (3) (MayJune, 1980), pp. 203-209.

Moran, Michelle T., Colonizing Leprosy: Imperialism and the Politics of Public Health in the United States (Chapel Hill: University of North Carolina Press, 2007).

Ricketts, T. F., The Diagnosis of Smallpox (New York: Cassell and Company, 1908).

Rooyen, C. E. and R. S. Illingworth., "A Laboratory Test for Diagnosis of Smallpox," British Medical Journal 2 (4372) (1944), pp. 526-529.

Smillie, W. G., "The National Board of Health 1879-1883," American Journal of Public Health and the Nation's Health 33 (8) (August 1943), pp. 925-929.

Tate, E. Mowbray, Transpacific Steam: The Story of Steam Navigation from the Pacific Coast of North America to the Far East and the Antipodes, 1867-1941 (Cranbury, NJ: Rosemont Publishing and Printing Corporation, 1986).

"The Fleets: Toyo Kisen Kabushiki Kaisha/ Toyo Kisen Kaisha/ Oriental Steamship Company, Yokohama," The Specialist, November 10, 2007 http://www. theshipslist.com/ships/lines/tkk. shtml. Accessed 10 August 2019.

Toomey, John A. and John A. Gammel, "The Paul Test in the Diagnosis of Smallpox," Journal of Infectious Disease 41 (1) (1927), pp. 29-31.

Willrich, Michael, Pox: An American History (New York: Penguin Books, 2011). 


\section{-Abstract- \\ Rethinking the History of Smallpox in the Early Twentieth Century: The SS Korea and Uncertainty Surrounding the Diagnosis of Smallpox}

LEE Hyon Ju*

This research explores the case of the 1903 smallpox outbreak on the SS Korea, a transpacific carrier making runs between Southeast Asia, East Asia, Hawaii, and the United States. These regions were connected to a degree that no one had ever imagined through the SS Korea. Honolulu, Hawaii, was one of the most important territories in US maritime history and served as a waypoint between Asia and San Francisco on the mainland. As increasing numbers of people traveled by sea, various microbes were communicated across the Pacific Ocean. International tourists traveling across the ocean to Hawaii and the United States were alerted to infectious diseases, smallpox being one of the most significant of such diseases.

The story of the SS Korea serves as an important lens through which

\footnotetext{
* Research Professor, Department of History, Ewha Womans University / E-mail: maat782000@gmail.com
}

Received: Jan. 31, 2020; Reviewed: Mar. 05, 2020; Accepted: Apr. 08, 2020 
LEE Hyon Ju : Rethinking the History of Smallpox in the Early Twentieth Century:

The SS Korea and Uncertainty Surrounding the Diagnosis of Smallpox

to explore the early twentieth century transpacific world connected through Honolulu. Focusing on the spread of smallpox via international travelers, this research studies aspects of the public health system that were developed to contain smallpox infection on international ships and the application of smallpox vaccination as a method for infectious disease control. More importantly, in bringing attention to the uncertainty surrounding the diagnosis of smallpox, this research argues for the necessity of historians to build a more comprehensive medical historical context for disease control systems that includes the limits of medical science in making diagnoses of infectious diseases, the uncertainties arising from a lack of this component, and the implementation of health policies and preventative medical technologies.

Keywords: smallpox, quarantine, vaccination, maritime disease control, diagnosis, 천연두, 격리, 백신접종, 해상질병통제, 진단 